\title{
The Role of Matra Basti with Bala taila in Sandhigata Vata w.s.r to ability to Climbing stairs in patients of osteoarthritis - Knee Joint
}

\author{
Research Article
}

\author{
Vats Anurag $^{1 *}$, Bharadwaj Shreyasi $^{2}$, Sharma Satish $^{3}$, Richa $^{4}$
}

1. Assiatant Professor, Uttarakhand Ayurved University, Gurukul Campus, Haridwar, Uttarakhand

2. PG Scholar, Munial Institute of Ayurveda Medical Science, Manipal, Udupi, Karnataka

3. Lecturer, ITS Paramedical College, Muradnagar, Ghaziabad, Uttar Pradesh

4. Assistant Professor, ITS Paramedical College, Muradnagar, Ghaziabad, Uttar Pradesh

\begin{abstract}
Aims and Objectives: Aim to investigate whether the procedure of Matra Basti with Bala Taila has any effect on the symptom of difficulty in climbing up-stairs and down-stairs in the patients of Osteoarthritis of Knee Joints.

Materials and Methods: A total of 20 patients having Osteoarthritis of knee joints were included in the present study. Patients were administered with "Matra Basti using Bala Taila" after giving snehan and svedana to them. The time of administration of Basti, time of expulsion and samyaka anuvasita lakshanas were noted on each day. The readings for climbing up-stairs and climbing down-stairs were noted before treatment and after treatment of 7 days.
\end{abstract}

Observation: Twenty patients of osteoarthritis of knee joint of age group 40 to 70 years irrespective of sex, religion and socioeconomic status were included for the study. Patients having systemic disorders, which might interfere with the treatment and those having traumatic conditions were not part of study.

Results: The study showed significant improvement in Ability to climbing up-stairs and down-stairs scores after administration of Matra Basti with Bala Taila.

Conclusion: The administration Matra Basti of Bala Taila has significant results in the management of the symptom of difficulty in climbing up-stairs and down-stairs in the patients of Osteoarthritis of Knee Joints

Keywords: Bala Taila, Matra Basti, Sandhigata Vata, Janu, Osteoarthritis, Knee Joint

\section{Introduction}

Ayurveda propagates wholesome health. Its objectives are to preserve the health of the healthy and cure the ailment of the ailed. These objectives lead to an improved quality of life for all people. There are innumerable diseases that are barriers in attaining these objectives.

All the diseases in the body whether in shakha, kostha or marma pradesha are influenced mainly by vata. Prakupita Vata is responsible for several types of diseases in body (1). Sandhi-gata-vata is one such disease in which the vitiated vata localizes in the asthisandhis of the body. It is a condition common in the vriddha awastha coinciding with the vata predominant phase of life. Such a condition, when affecting the knee

*Corresponding Author:

\section{Vats Anurag}

Assiatant Professor, Uttarakhand Ayurved

University, Gurukul Campus, Haridwar,

Uttarakhand

E-mail: ayurvatsam@gmail.com;

Ph:- +91-9888737390 joints, is termed as JanuSandhigatavata. In ayurvedic terminology, janu refers to the knee joint.

Sandhigata vata is correlated with Osteoarthiritis. It is a degenerative joint disorder which may begin asymptomatically in the second and third decades of life (2). Knee joint is a common site for osteoarthiritis. The major risk factors associated with knee joint are old age, female sex, obesity and occupational knee-bending. Its treatment includes administration of pain killers like NSAIDS (non steroidal anti inflammatory drugs), Narcotics, Corticosteroids, Intra articular injections and other remedies, which gives only temporary relief. Surgery (Knee replacement) is the last resort. These are quite expensive, need hospitalization and often cause adverse effects.

Osteoarthritis is the most common form of arthritis. It is a degenerative type of arthritis which mainly occurs in old age. Degeneration takes place in the joint which makes the individual disabled or handicapped. Degeneration occurs continuously in most of the patients which makes the person disabled for life long. It is a chronic degenerative disorder of multi- 
factorial etiology characterized by loss of articular cartilage and periarticular bone remodeling. It involves the entire joint including the nearby muscles, underlying bone, ligament, synonium and capsule. The risk factors for osteoarthritis are old age, obesity, female sex, major joint trauma, repetitive stress, genetic factors, prior inflammatory joint diseases and metabolic or endocrine disorders.

Symptoms of Sandhigatavata are Sandhishula, Sandhishotha, Akunchana Prasarana Janya Vedana and Hanti Sandhi Gati described by various Acharya. Here, Sandhishula and Sandhishotha occur due to Vataprakopa. A special type of Shotha i.e. Vatapurnadriti-sparsha or Atopa is mentioned which indicates Vata dominancy of Shotha. Akunchana-prasaranjanyavedana and Hanti-sandhi-gati occurs due to Kaphakshya and Vata Prakopa.

Acharya Charaka has mentioned repeated use of Snehana, Svedana, Basti and Mrudu Virechana for the treatment of Vatavyadhi. He has not mentioned the treatment of Sandhigatavata separately. Acharya Sushruta has described specific treatment for the Sandhigatavata first time i.e. Snehana, Upanaha, Agnikarma, Bandhana and Unmardana.

Basti Chikitsa is considered the best management of vitiated vata (3). The panchkarma procedure of Basti has been hailed as 'ardha chikitsa' by acharyas that is, half of the whole treatment (4). Anuvasana Basti is a type of Basti (5) in which Sneha dravya is given by Basti. Matra Bast (6)i is a type of Anuvasana Basti.(7) It is explained that this type of Basti can be given to almost everybody, in all the seasons, without any strict regime of ahara and vihara and it is nishpariharya(8); i.e, it can be given with maximum ease and has no complication thereafter.

Sandhigatavata is Kastasadhya vyadhi because all the Vatavyadhis are difficult to cure and they are said as Mahagada. So being a Vatavyadhi, Sandhigatavata is Kastasadhya. Madhyama Rogamarga, Situation in Marma Asthi Sandhi, Vitiation of Asthi and Majja, Dhatukshya, Vriddhavastha also makes it Kastasadhya.

Janu is a Sandhi Marma. It is explained in Charaka Samhita that for the management of the diseases at marma sthana, vata dosa should be treated (9). Basti is considered most effective for the management of vata; summing the above points Basti might be considered most rewarding in the treatment on Janusandhigata vata.

Charaka refers to taila as 'marutaghana'. Taila is mentioned to reduce vata without increasing kapha. It also stabilizes the mansa dhatu (10). Taila is used as drug of choice in anuvasana Basti. Due to its sneha property it balances the rooksha guna of vayu, due to its guru guna treats laghu guna of vayu and due to its ushna guna takes care of the sheethala guna of vayu. Acharya Sushruta mentions snehana (outer/internal) for management of Sandhigatavata (11). Asthi dhatu has kharatva which is also combated by taila. So we can say that taila can be used to treat sandhigata vata and bring normalcy to the dhatu.

In the present study Bala Taila is considered as sneha dravyas in Matra Basti for the management of Janusandhigata Vata. In Sahastrayogam, Bala Taila is mentioned as 'Shrestha Vata Vyadi Vinashanam' and thus, it can be used as a Sneha for Matra Basti (12).

\section{Methods \\ Study Design and Patients:}

A sample of 20 patients having Janu Sandhigatavata was selected for the study. All the patients were given Matra Basti with Bala taila.

Inclusion criteria were as follows: Patients with Pratyatma Laksana of Sandhigata Vata; Patients of age group 40 to 70 years irrespective of sex, religion and socioeconomic status; patients who are fit for Matra Basti and were willing to sign the informed consent.

Exclusion criteria were: Patients having systemic disorder which might interfere with the treatment, Patients who were not fit for Matra Basti, Patients with infective Neoplastic and traumatic condition of Knee joint.

\section{Procedure:}

The patients who fulfilled the inclusion criteria were subjected for routine Haematological examination and Antero-Posterior View \& Lateral View X-ray of affected Knee joint. Before commencement of the treatment an informed consent was taken from the patients, and the patients were evaluated for both Subjective and Objective parameters and grading were noted.

Patients were subjected to whole body snehana for 30 minutes followed by baspa sweda for 10 minutes. Bala taila was used for bahya snehana. The patients were asked to consume laghu and alpa ahara. The patient was then asked to attend natural urges and walk a few steps before reaching the Basti room.

The patient was advised to lie comfortably in left lateral position on a cot. The cot was of comfortable height. The patient was asked to lie with left leg stretched straight and the right leg flexed at knee and hip joints without support of pillow. The head resting on left hand with the right hand resting on the right leg. Bala Taila was taken in a small container. The taila was made lukewarm by keeping it in a vessel containing hot water.

The taila was taken in an enema syringe fitted with rubber catheter. The anal orifice and the tip of the catheter were lubricated with oil. After removing the air from the syringe and the catheter, the catheter was introduced into the anus gently upto 4 inches. The piston of the syringe was pressed gently and with uniform force and the taila was injected into the rectum.

The patient was asked to take deep breath and not 
to shake his body while introducing the catheter and drug. Small quantity of taila was retained in the syringe in order to avoid entry of air into the pakvashaya (intestine/ rectum). After the administration of Basti, the patient was advised to lie in supine position with hand and legs freely spread over the table. Thereafter both the legs of the patient were raised from the cot three times. The buttocks were gently tapped three times. Simultaneously taps were given on the soles and palms also. After sometime patient was advised to get up from the table and take rest and not to indulge in day sleep.

The time of administration of Basti, time of expulsion and samyaka anuvasita lakshanas were noted on each day. The readings for ability to climb-up standard flight of stairs and ability to climb-down standard flight of stairs were noted before treatment and after treatment of 7 days.

The subjective criteria were scored in accordance with Index of severity of Osteoarthritis of the Knee by Lequesne et al.

\begin{tabular}{|c|l|c|}
\hline Parameters & \multicolumn{1}{|c|}{ Findings } & Points \\
\hline Ability to & Easily & 0 \\
climb up a & With mild difficulty & 1 \\
standard & With moderate difficulty & 2 \\
flight of & With marked difficulty & 3 \\
stairs & Unable & 4 \\
\hline Ability to & Easily & 0 \\
climb down & With mild difficulty & 1 \\
a standard & With moderate difficulty & 2 \\
flight of & With marked difficulty & 3 \\
stairs & Unable & 4 \\
\hline
\end{tabular}

The patients were assessed on the first day (before starting the treatment) and 7th day (after completion of treatment). Follow up were also taken after 7 days of The patients were assessed on the first day (before starting the treatment) and 7th day (after completion of treatment). Follow up were also taken after 7 days of completion of treatment, but it was not included in discussing the results. As there is no strict restriction of diet and regimen for Matra Basti, no strict Pathya-Apathya was advised. If the patient develops urge to defecate or micturate or to pass flatus, then the Bastinetra should be removed, after completion of the urges the remaining medicines should be administered.

\section{Ethics}

The procedures in the present study were in accordance with the ethical standards of the responsible committee. Patients were given information saying that participation was voluntary and that they could choose not to participate at any time without having to give a reason.

\section{Data analysis}

A pre- test, post- test experimental group design was used for the study. Data was tabulated on master chart. Statistical analysis was performed using SPSS 16.0 version software. Independent $T$ test was used for the analysis of pre treatment and post treatment finding. Significance level was set at $\mathrm{P}<0.05$.

\section{Results}

A statistically significant difference was observed within pre and post reading of ability to climb-up standard flight of stairs and ability to climb-down standard flight. Pre and post analysis was done by Independent $\mathrm{T}$ test.

\begin{tabular}{|c|c|c|c|c|c|c|c|c|}
\hline Symptom & \multicolumn{3}{|c|}{ Mean Scores } & Difference in Mean & \% & S.D $( \pm)$ & t value & p value \\
\hline \multirow{2}{*}{ Climb Up Stairs } & BT & AT & 1.60 & 0.80 & 33.33 & 0.75 & 8.718 & $\mathrm{p}<0.05$ \\
\cline { 2 - 9 } & 2.40 & $1^{\text {st }} \mathrm{FU}$ & 1.25 & 1.15 & 47.91 & 0.71 & 14.038 & $\mathrm{p}<0.05$ \\
\hline
\end{tabular}

An assessment of ability to climb up Standard flight of stairs in patients of Janu sandhigatavata before and after treatment was taken and analyzed statistically. The mean score which was 2.40 before treatment came to 1.60 after the. Analysis of the data shows statistically significant improvement $(\mathrm{p}<0.05)$.

\begin{tabular}{|c|c|c|c|c|c|c|c|c|}
\hline \multirow{2}{*}{ Symptom } & \multicolumn{3}{|c|}{ Mean Scores } & Difference in Mean & $\%$ & S.D $( \pm)$ & t value & $p$ value \\
\hline \multirow{2}{*}{ Climb Down Stairs } & BT & AT & 1.70 & 0.40 & 19.04 & 0.73 & 2.990 & 0.008 \\
\cline { 2 - 11 } & 2.10 & $1^{\text {st }} \mathrm{FU}$ & 1.05 & 1.05 & 50 & 0.68 & 5.688 & $\mathrm{p}<0.05$ \\
\hline
\end{tabular}

An assessment of ability to climb down standard flight of stairs in patients of Janu sandhigatavata before and after treatment was taken and analyzed statistically. The mean score which was 2.10 before treatment came to 1.70 after the treatment. Analysis of the data shows statistically significant improvement $(\mathrm{p}<0.05)$. 
Figure 1, showing pre-post analysis of ability to climb-up standard flight of stairs

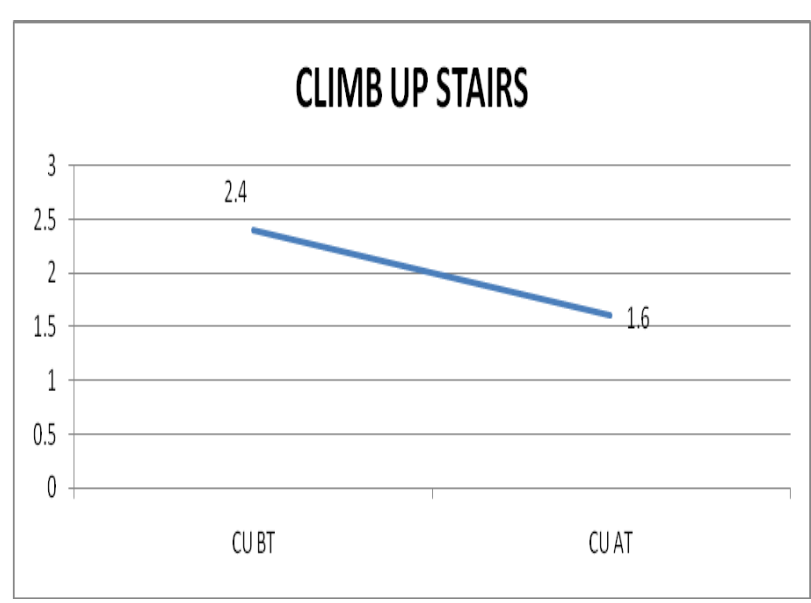

\section{Discussion}

Vata and Asthi have Ashraya-Ashrayi Sambandha, this means that Vata is situated in Asthi. Vriddha- Increased Vata diminishes Sneha from A sthidhatu due to its opposite qualities to Sneha. Due to diminution of Sneha, Khavaigunya (Rikta Srotas) occurs in Asthi which is responsible for the production of Sandhigatavata.

Sandhigatavata is described in all Samhita and Sangrahagrantha under Vatavyadhi. Various Aharaja, Viharaj, Manasa and other Vata Prakopaka Nidanas are mentioned in detail for the occurrence of Vatavyadhi. Though, Sandhigatavata usually occurs in Vriddhavastha which is parihanikala in which Dhatukshya takes place which leads Vataprakopa.

In the Samprapti of Sandhigatavata, Prakupita Vata gets situated in Asthi Sandhi where Khavaigunya Rikta Srotas is already present. Then Dosha Dushya Sammucchana takes place in Asthi Sandhi and further in Samprapti, the disease Sandhigatavata appears with its symptoms.

Ability to climb-up Stairs: There was a significant improvement in the ability to climb up stairs observed after treatment and after treatment $(\mathrm{p}<0.05)$.

Ability to climb-down Stairs: There was a significant improvement in the ability to climb down stairs observed after treatment and after final treatment $(\mathrm{p}<0.05)$. As mentioned earlier Basti Chikitsa is considered the best management of vitiated vata (3).

In the present study taila which is described as being as 'marutaghana' without increasing kapha is used due to its sneha property, guru guna and ushna guna which collectively are treating vayu. Also, Bala taila is used among the tailas because it is described as 'Shrestha Vata Vyadi Vinashanam'.

Thus, the use of Basti (Matra Basti) having taila as sneha dravya, and taila used is Bala taila collectively
Figure 2, showing pre-post analysis of ability to climb-down standard flight of stairs

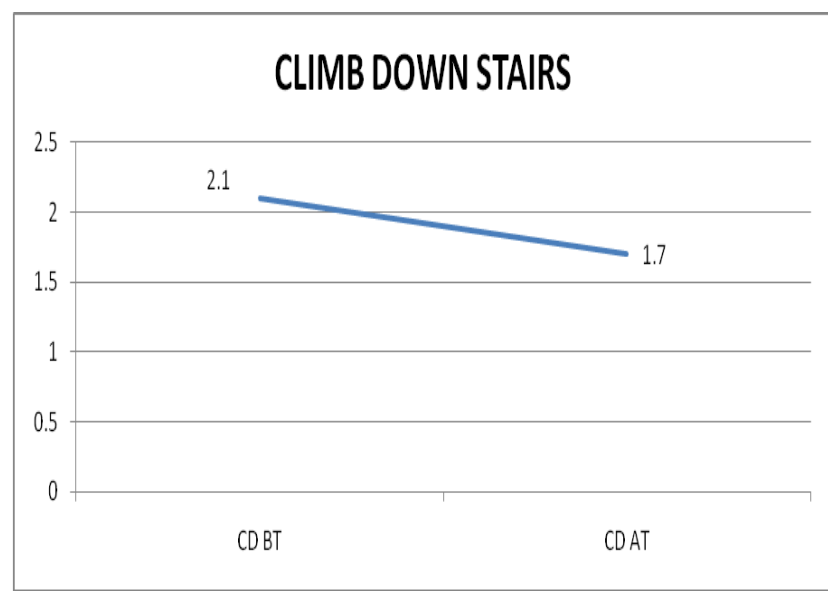

becomes very fruitful for the management of Janu Sandhigatavata.

\section{Scope of Future Research}

- Larger number of sample size should be included to confirm our results and generalize the results to population outside this sample population.

- Other parameters like pain, stiffness, difficulty in walking etc. should also be assessed for the patients.

- Same procedure using other taila should be studied to compare the relative efficacy of different tailas.

\section{Conclusion}

The present study is an attempt to explore the efficacy of Matra Basti in the management of Sandhigatavata. Bala taila has been used and its effects were verified based on the parameter of ability to climb stairs (up and down). Matra Basti can be used effectively and with ease in management of Sandhigata vata. Since it is one of the simplest forms of Basti and involves no complications it can be administered without much hassles or prolonged preparations. The ease of the procedure can be an encouraging factor for the physician to employ Panchakarma to provide relief to the patient.

\section{References}

1. Agnivesh, Charaka Samhita; Pandit Kashi nath Shasty \& Dr. Gorakhnath Charurvedi, Vol-I, Reprint 2001; Chaukhamba Bharati Academy, Varanasi; Pp. 1024, Pg. 249. (Ch. Su. 12/8)

2. Arthritis Ireland (2009) 'Facts about Arthritis' accessed at http://www.arthritisireland.ie/info/ facts.php January 2010.

3. Agnivesh, Charaka Samhita; Pandit Kashi nath Shasty \& Dr. Gorakhnath Charurvedi, Vol-I, $25^{\text {th }}$ Edition, Reprint 1995; Chaukhamba Bharati Academy, Varanasi; Pp. 1024, Pg. 468. (Ch. Su. 25/40) 
4. Agnivesh, Charaka Samhita; Pandit Kashi nath Shasty \& Dr. Gorakhnath Charurvedi, Vol-II, $25^{\text {th }}$ Edition, Reprint 2009; Chaukhamba Bharati Academy, Varanasi; Pp. 1208, Pg. 971. (Ch. Si. 1/39)

5. Agnivesh, Charaka Samhita; Pandit Kashi nath Shasty \& Dr. Gorakhnath Charurvedi, Vol-II, 25 ${ }^{\text {th }}$ Edition, Reprint 2009; Chaukhamba Bharati Academy, Varanasi; Pp. 1208, Pg. 1077. (Ch. Si. 10/8)

6. Agnivesh, Charak Samhita; Pandit Kashi nath Shasty \& Dr. Gorakhnath Charurvedi, Vol-II, $25^{\text {th }}$ Edition, Reprint 2009; Chaukhamba Bharati Academy, Varanasi; Pp. 1208, Pg. 1013. (Ch. Si. 4/53)

7. Vridha Vagbhata, Astanga Samgraham; Kaviraj Atri dev Gupt, Vol-I, Edition 1993; Krishna Das Academy, Varanasi; Pp. 408, Pg. 206.

8. Vridha Vagbhata, Astanga Samgraham; Kaviraj Atri dev Gupt, Vol-I, Edition 1993; Krishna Das Academy, Varanasi; Pp. 408, Pg. 206. (As. Sa. 28/8)
9. Agnivesh, Charaka Samhita; Pandit Kashi nath Shasty \& Dr. Gorakhnath Charurvedi, Vol-II, 25 ${ }^{\text {th }}$ Edition, Reprint 2009; Chaukhamba Bharati Academy, Varanasi; Pp. 1208, Pg.1053. (Ch. Si. 9/7)

10. Agnivesh, Charaka Samhita; Pandit Kashi nath Shasty \& Dr. Gorakhnath Charurvedi, Vol-I, 25 Edition, Reprint 1995; Chaukhamba Bharati Academy, Varanasi; Pp. 1024, Pg. 258. (Ch. Su. 13/15)

11. Sushruta, Sushruta Samhita; Dr Ambika Dutt Shastri, Vol-I, Edition 2007, Chaukhambh Sanskrit Sansthan, Varanasi; Pp. 303, Pg. 230. (Su. Sa. Ni. $1 / 28)$

12. Sahastrayogam, Dr. R. Nisteshwar; IInd Edition, 2008, Chaukhanbha Sanskrit Series, Varanasi; Pp.540, Pg.152. (Taila Prakarana) 